\title{
Bioattenuation in Groundwater Impacted by Landfill Leachate Traced with $\delta^{13} \mathrm{C}$
}

\author{
by Hossein Mohammadzadeh ${ }^{1}$ and lan Clark $^{2}$
}

\begin{abstract}
The impact on groundwater imparted by the infiltration of high dissolved organic carbon (DOC) leachate from capped, unlined landfills can be attenuated by biogeochemical reactions beyond the waste source, although such reactive loss in the aquifer is difficult to distinguish from conservative advective dispersion. Compoundspecific measurement of $\delta^{13} \mathrm{C}$ in carbon species, including $\mathrm{CH}_{4}$, dissolved inorganic carbon (DIC), and the major DOC compounds (acetate, humic acid, and fulvic acid) provides a constraint in this assessment that can assist in exercises of modeling and prediction of leachate transport. The Trail Road municipal landfill near Ottawa, Ontario, Canada, hosts an unlined sector which produces a highly enriched leachate (DOC $>4500 \mathrm{mg} / \mathrm{L}$ ) that provides a good site to examine reactive attenuation within the receptor aquifer. Acetate, a sentinel component of leachate DOC $(\sim 1000 \mathrm{mg} \mathrm{C} / \mathrm{L})$, is absent in impacted groundwater. Mass balance calculations together with reaction modeling suggest continued acetate fermentation with calcite control on DIC and $\delta^{13} C_{\text {DIC }}$ evolution. In groundwater within $50 \mathrm{~m}$ of the landfill, methane concentrations are elevated $(\sim 10 \mathrm{mg} / \mathrm{L})$, consistent with acetate fermentation, whereas $\delta^{13} \mathrm{C}_{\mathrm{CH} 4}$ measurements in deeper groundwater range down to $-51 \%$ o compared with $-60 \%$ o in the landfill demonstrating oxidative loss. DOC in the deep aquifer is remarkably depleted to values less than $-40 \%$ o suggesting methanotrophic bacteria selectively consume isotopically light $\mathrm{CH}_{4}$ to fix carbon. Continued reaction of leachate DOC in groundwater is demonstrated by evolution away from conservative mixing lines on diagrams of $\delta^{13} \mathrm{C}$ vs. concentrations of DIC and DOC.
\end{abstract}

\section{Introduction}

Leakage of landfill leachate from legacy landfills that lack engineered liners can be a chronic source of groundwater contamination (e.g., Mackay et al. 1985; Lo 1996; El Fadel et al. 1997; Kjeldsen et al. 2002; Kurniawan et al. 2006). Although usually capped to minimize infiltration and leachate production, this results in considerably higher concentrations of hazardous dissolved

${ }^{1}$ Corresponding author: Groundwater Research Center, Faculty of Science, Ferdowsi University of Mashhad, P.0. Box 917751436, Mashhad, Iran; (98) 511 8797275; fax: (98) 511 8797275; mohammadzadeh@um.ac.ir,mohammadzadeh@alumni. uottawa.ca

${ }^{2}$ Department of Earth Sciences, University of Ottawa, 140 Louis Pasteur, Ottawa, ON K1N 6N5, Canada; idclark@uottawa.ca

Received November 2008, accepted December 2010.

(C) 2011, The Author(s)

Ground Water (C) 2011, National Ground Water Association.

doi: $10.1111 / j .1745-6584.2010 .00790 . x$ organic carbon (DOC) compounds (Rovers and Farquhar 1973; El Fadel et al. 1997). Subsequent impact on groundwater can be partially mitigated by dilution during advective dispersion in groundwater but potentially by further biogeochemical reaction and degradation within the aquifer. Although estimates of dilution can be made on the basis of conservative transport modeling, demonstrating the degradation of organic carbon within the plume is more challenging given the heterogeneity in leachate composition within a landfill. Kjeldsen et al. (2002) reviewed the sequence of leachate evolution in municipal solid waste landfills in the final anaerobic stage. Hydrolysis and anaerobic degradation of cellulosic and hemicellulosic materials in landfills contribute to the generation of labile organic components ranging from light fatty acids to high-molecular weight humic and fulvic components as well as dissolved inorganic carbon (DIC) and $\mathrm{CH}_{4}$ (Christensen et al. 1998). Following the initial aerobic and acidic phases, fermentative bacteria hydrolyze and 
ferment primary organic polymers to produce carboxylic and fatty acids according to reactions such as the formation of butanoic acid:

$$
\mathrm{C}_{6} \mathrm{H}_{12} \mathrm{O}_{6} \rightarrow \mathrm{CH}_{3} \mathrm{CH}_{2} \mathrm{CH}_{2} \mathrm{COOH}+2 \mathrm{CO}_{2}+2 \mathrm{H}_{2}
$$

and acetic acid:

$$
\mathrm{CH}_{3} \mathrm{CH}_{2} \mathrm{CH}_{2} \mathrm{COOH}+2 \mathrm{H}_{2} \mathrm{O} \rightarrow 2 \mathrm{CH}_{3} \mathrm{COOH}+2 \mathrm{H}_{2}
$$

with net production of DOC, hydrogen gas, and $\mathrm{CO}_{2}$. Acetotrophic and hydrogenotrophic methanogens are active at this stage, converting these end products to $\mathrm{CH}_{4}$ and $\mathrm{CO}_{2}$ :

$$
\begin{aligned}
& \mathrm{CH}_{3} \mathrm{COOH} \rightarrow \mathrm{CH}_{4}+\mathrm{CO}_{2} \\
& \mathrm{CO}_{2}+4 \mathrm{H}_{2} \rightarrow \mathrm{CH}_{4}+2 \mathrm{H}_{2} \mathrm{O} \quad \text { (Klass 1984) }
\end{aligned}
$$

In this stage of maximum methanogenesis, a recalcitrant organic reservoir of higher weight compounds including humic and fulvic and hydrophilic fractions begins accumulating (Christensen et al. 1998). The reservoir of dissolved carbon is then characterized by humic and fulvic acids, acetate, and other light-weight fatty acids plus the dissolved methane and inorganic carbon (essentially $\mathrm{HCO}_{3}{ }^{-}$). There is a considerable range in concentrations of these components of the carbon pool (Kjeldsen et al. 2002; Mohammadzadeh et al. 2005) and so assessing the degree of degradation following dilution with the impacted groundwater on the basis of compound ratios is not possible. In contrast, biogeochemical reactions associated with the transformation of DIC and DOC compounds within the landfill environment produce characteristic ${ }^{13} \mathrm{C}$ signatures that serve to demonstrate attenuation through reactive biodegradation. The fractionation of ${ }^{13} \mathrm{C}$ during generation of DOC, DIC, and $\mathrm{CH}_{4}$ within the landfill leachate has been recognized and characterized in a number of studies (Liu et al. 1992; Fritz et al. 1994; Hackley et al. 1996, 1999; Desrocher and Lollar 1998; North et al. 2006). More recently, isotopic characterization of separated compounds of DOC offers greater insights into ${ }^{13} \mathrm{C}$ partitioning and reactions during biodegradation in landfill leachate (Mohammadzadeh et al. 2005; North et al. 2006). In the case of the Trail Road Landfill (TRL), compoundspecific isotope analysis of leachate DOC fractions show partitioning of ${ }^{13} \mathrm{C}$ exceeding $10 \%$ during leachate generation (Mohammadzadeh and Clark 2008). The substantial bacterial fractionation associated with DOC degradation can then be used to distinguish continued biodegradation of DOC in groundwater from nonreactive advective dispersion for transport modeling. For example, continued fermentation of elevated DOC in the proximal zones of the leachate plume may add ${ }^{13} \mathrm{C}$-enriched $\mathrm{CO}_{2}$ to the DIC pool, whereas oxidation of DOC in the distal part of the plume will impart a negative shift in ${ }^{13} \mathrm{C}_{\mathrm{DIC}}$ for the gained DIC.

Compound-specific isotope $\left({ }^{13} \mathrm{C}\right)$ analysis is undertaken here for groundwater samples collected from the
TRL site. The leachate from unlined parts of the TRL (Stages 1 and 2) and the adjacent unlined Nepean landfill is recognized as the main source of organic carbon contamination that has been observed in the downgradient groundwater. The objective of this work is to evaluate the use of ${ }^{13} \mathrm{C}$ in $\mathrm{DIC}, \mathrm{CH}_{4}$, and DOC fractions, in conjunction with conservative leachate dilution pathways, to recognize continued degradation of organic compounds in leachate-impacted groundwater. Excursions from dilution pathways can then be used to elucidate the nature and extent of continued biogeochemical reaction and degradation within the leachate-impacted groundwater.

\section{Hydrogeological and Geochemical Setting of the TRL}

The TRL is owned and operated by the City of Ottawa and is located approximately $25 \mathrm{~km}$ west of the city (Figure 1). The TRL is divided into Stages 1 through 4. Stages 3 and 4 were opened in 1991 and feature basal leachate collection and recirculation systems underlain by an engineered barrier of clay, sand, and PVC liner. Only Stage 4 remains uncapped and in active operation (City of Ottawa 2002; Dillon Consulting Ltd. 2006). Stages 1 and 2 (Figure 1), which are up to 30 years old, are capped but unlined and without leachate collection systems and so represent the source of leachate contamination of the underlying aquifers.

The site is underlain by both a shallow and a deep aquifer, separated by a discontinuous clay aquitard that is present in the northern and western portions of the site but absent below the southern half of Stages 1 and 2. Above the clay aquitard, shallow groundwater flows northward and follows the general slope of the underlying clay which varies approximately $20 \mathrm{~m}$ in elevation over the study area. In the deep aquifer, flow is northwest toward a dewatering pond (DWP). More than 200 individual and nested piezometers were installed by the City of Ottawa to sample groundwater (Figure 1) (City of Ottawa 2002; Golder Associates Ltd. 2003; Dillon Consulting Ltd. 2006).

Leachate impact has been identified largely on the basis of $\mathrm{CH}_{4}, \mathrm{Cl}^{-}, \mathrm{Br}^{-}$, and $\mathrm{NH}_{4}^{+}$in both shallow and deep aquifers along the north border of the unlined parts of the TRL site (Dillon Consulting Ltd. 2006). Piezometers completed in the shallow aquifer (M4-2 and M37-3 north border of Stages 1 and 2, respectively) and in the deep aquifer (M4-1, M37-2, M39-7, and M16-2) were selected for detailed sampling and analysis (Figure 1). Review of the available geochemical data (City of Ottawa 2002; Golder Associates Ltd. 2003; Dillon Consulting Ltd. 2006) showed no evidence of leachate indicator parameters in upgradient (M57) and downgradient (M120) groundwater, which were sampled in this study as representative background (unimpacted) groundwater.

\section{Field Sampling and Analytical Methods}

Field geochemical parameters, including temperature $(T), \mathrm{pH}$, electromotive potential (Eh), and dissolved 


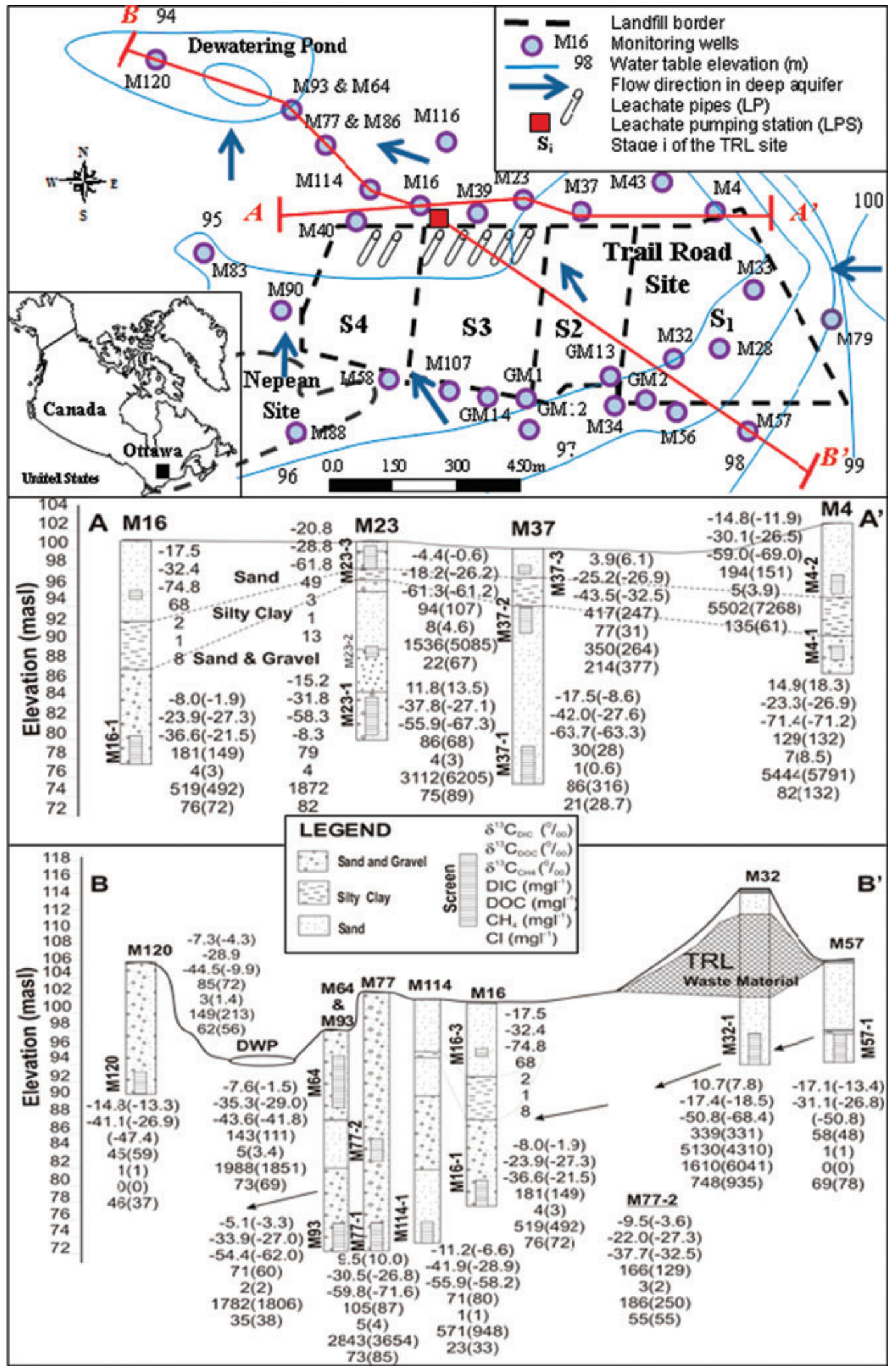

Figure 1. Plan view of study area and flow direction in the deep aquifer. Geological cross section parallel to landfill border $\left(\mathrm{AA}^{\prime}\right)$ and at groundwater flow directions in the deep aquifer $\left(\mathrm{BB}^{\prime}\right)$ which shows both shallow and deep aquifers, separated by a discontinuous clay aquitard. The concentrations and $\delta^{13} \mathrm{C}$ values of major carbon fractions for 2004 sampling (and 2005 sampling between parentheses) are shown in different levels (screens) on the well logs. 
oxygen (DO) were measured in an in-line flow-through cell through which groundwater was circulated with a peristaltic pump. Samples for major anions and cations and $\delta^{2} \mathrm{H}$ and $\delta^{18} \mathrm{O}$ of water were filtered with $0.45-\mu \mathrm{m}$ filter disks and collected in 30-mL high-density polyethylene plastic bottles. Cation samples were acidified with $0.1 \mathrm{~mL}$ ultrapure nitric acid. To measure concentrations and $\delta^{13} \mathrm{C}$ of DIC and DOC, 40-mL filtered samples were collected using amber glass bottles. Methane samples (concentration and isotopes) were collected unfiltered in $125-\mathrm{mL}$ Wheaton glass bottles to measure the methane concentration and isotopes. Bulk samples for separation of DOC compounds, including acetate, humic acid (HA), fulvic acid (FA), and light-molecular weight dissolved carbon (LMW DOC), were collected in 4-L amber glass containers and kept cool prior to lab filtering $(0.45 \mu \mathrm{m})$ and analysis within a 2 -week period.

The $\delta^{18} \mathrm{O}$ and $\delta^{2} \mathrm{H}$ of the water samples were measured by routine $\mathrm{CO}_{2}$ and $\mathrm{H}_{2}$ equilibration using a Gasbench and DeltaPlus XP continuous-flow isotope-ratio mass spectrometer (CF-IRMS, with an analytical precision of $\pm 0.15 \%$ ond $\pm 2.0 \%$, respectively). The concentration and ${ }^{13} \mathrm{C}$-isotopic composition of DIC plus both bulk DOC and separated DOC compounds were measured using a Total Carbon Analyzer (TCA-OI Instruments Model 1010) interfaced with CF-IRMS. Here, samples are initially acidified $\left(5 \% \mathrm{H}_{3} \mathrm{PO}_{4}\right)$ and purged of $\mathrm{CO}_{2}$ for measurement of DIC and $\delta^{13} \mathrm{C}_{\mathrm{DIC}}$ by advection of sample $\mathrm{CO}_{2}$ in an $\mathrm{He}$ stream through a nondispersive infrared detector and then through a ConFlow III interface for $\delta^{13} \mathrm{C}$ measurement by IRMS (St-Jean 2003). This is followed by a DOC oxidation step $\left(\mathrm{Na}_{2} \mathrm{~S}_{2} \mathrm{O}_{8}\right)$ and second purge of $\mathrm{CO}_{2}$ for measurement of DOC and $\delta^{13} \mathrm{C}_{\mathrm{DOC}}$.

The isolation of dissolved humic compounds was carried out by acid precipitation of HA and column separation of remaining FA and LMW DOC. Four-liter samples were filtered using $0.7 \mu \mathrm{m}$ glass-microfiber filters (Whatman cat No. 1825047) and acidified to below pH 2 with concentrated $\mathrm{HCl}$ to precipitate and then filter out $\mathrm{HA}$. The FA of the samples was separated from the LMW DOC fraction using Superlite DAX-8 adsorbent resin. All collected samples were analyzed with the TCA interfaced to the IRMS (aforementioned) to obtain carbon concentrations and $\delta^{13} \mathrm{C}$ values of DOC fractions following the protocols presented by Mohammadzadeh et al. (2005).

The carbon content and ${ }^{13} \mathrm{C}$ in solid (precipitated) HA samples were analyzed by flash combustion at $1800{ }^{\circ} \mathrm{C}$ with a Carlo Erba Flash Elemental Analyzer equipped with a thermal conductivity detector and configured inline with a Delta plus CF-IRMS. The routine analytical precision $(2 \sigma)$ is $\pm 0.1 \%$ for concentration and $\pm 0.15 \%$ o for ${ }^{13} \mathrm{C}$.

Carbon concentration and isotope mass balance calculations, according to Equation 1, show that the efficiency of the DAX-resin column for collection of organic carbon fractions shows that recoveries are $>92.8 \%$.

$$
\begin{aligned}
\delta^{13} \mathrm{C}_{\mathrm{DOC}} \times \mathrm{C}_{\mathrm{DOC}}= & \left(\delta^{13} \mathrm{C}_{\mathrm{HA}} \times \mathrm{C}_{\mathrm{HA}}\right)+\left(\delta^{13} \mathrm{C}_{\mathrm{FA}} \times \mathrm{C}_{\mathrm{FA}}\right) \\
& +\left(\delta^{13} \mathrm{C}_{\mathrm{LMW} \text { DOC }} \times \mathrm{C}_{\mathrm{LMW} \text { DOC }}\right)(1)
\end{aligned}
$$

Headspace samples were analyzed for methane concentration, $\delta^{13} \mathrm{C}_{\mathrm{CH} 4}$ and $\delta^{13} \mathrm{C}_{\mathrm{CO} 2}$ using a gas chromatography (GC) combustion system (GCC III) interfaced with a CFIRMS. The analytical precision for $\delta^{13} \mathrm{C}$ was $\pm 0.2 \%$ o to $\pm 0.3 \%$. All measurements were performed in the Geochemistry and the G.G. Hatch Stable Isotope Laboratory at the University of Ottawa.

\section{Results and Discussion}

Averaged results of replicate sampling for field parameters, cations and anions, and calculated calcite saturation index $\left(\mathrm{SI}_{\mathrm{cal}}\right)$, and the results of isotopic analysis are summarized in Tables 1 and 2, respectively. Data for individual samples (collected 2003 through 2005) are available in supporting information. Leachate impact has been studied here in monitoring wells M4-1, M4-2, M372, M23-1, and M23-2, situated parallel to the landfill border $\left(\mathrm{AA}^{\prime}\right)$ and along the deep aquifer groundwater flow direction $\left(\mathrm{BB}^{\prime}\right)$. The major ion geochemistry of these groundwater samples is characterized by a $\mathrm{Ca}$ $\mathrm{HCO}_{3}$ facies.

Figure 1 details the well $\operatorname{logs}$ and the carbon geochemistry and $\delta^{13} \mathrm{C}$ of leachate-impacted groundwater. Measurements of DOC and $\mathrm{CH}_{4}$ for M32 (4310 to $5130 \mathrm{mg} / \mathrm{L}$ and 1.6 to $6.0 \mathrm{mg} / \mathrm{L}$, respectively) are used as the source term for the input of the leachate from the unlined landfill. Impact in adjacent groundwater is demonstrated by the presence of methane as well as by high concentrations of ${ }^{13} \mathrm{C}$-enriched DIC. Background groundwater (BG) is characterized by low DOC and no methane (upgradient M57 and downgradient M120) (Section BB').

\section{Evolution of Dissolved Carbon and ${ }^{13} \mathrm{C}$ in Leachate-Impacted Groundwater}

Although a bulk parameter, DOC, together with $\delta^{13} \mathrm{C}_{\mathrm{DOC}}$, is used for evidence of potential reaction following mixing with groundwater. The effect of capping, which resulted in a decrease in leachate production, is shown by the response in M33, completed in the shallow aquifer within the boundaries of Stage 1, where DOC dropped rapidly immediately after capping of this stage in 1988 (Figure 2a). The shallow groundwater in M4-2 and to a lesser extent at M37-3 follows similar attenuation trends (Figure 2a) following capping of Stages 1 and 2.

Unlike the shallow aquifer, the DOC concentration in M32, completed in the zone of recharge to the deep groundwater within the boundaries of the Stage 1 landfill, was highly elevated in the past and has decreased from a peak in 1995, several years after Stage 1 was covered in 1988 (Figure 2b). Figure 2b shows DOC variations in the deep aquifer beyond the landfill at M4-1, M37-2, and M39-7 (located north of Stages 1, 2, and 3, respectively), with temporal trends similar to M32. The capping of Stages 1 and 2 reduced the leachate component infiltrating the deep aquifer, providing the attenuation observed in Figure $2 b$.

Figure 3 shows the concentration of DIC vs. $\delta^{13} C_{\text {DIC }}$ and DOC vs. $\delta^{13} \mathrm{C}_{\mathrm{DOC}}$ for the leachate and groundwater 
from different aquifers. Mixing lines were drawn based on $\delta^{13} \mathrm{C}$ mass balance between two end members including the BG (at M57) and leachate (M32), using Equations 2 and 3 .

$$
\begin{gathered}
\delta^{13} \mathrm{C}_{\text {Mixture }}=\frac{f\left(\delta^{13} \mathrm{C}_{\mathrm{DC}-\text { Leachate }} \times \mathrm{DC}_{\text {Leachate }}\right)}{f \times(1-f)\left(\delta^{13} \mathrm{C}_{\mathrm{DC}-\mathrm{BG}} \times \mathrm{DC}_{\mathrm{BG}}\right)} \\
\mathrm{DC}_{\text {Mixture }}=f \times \mathrm{DC}_{\text {Leachate }}+(1-f) \times \mathrm{DC}_{\mathrm{BG}}
\end{gathered}
$$

in which DC represents either DOC or DIC and $f$ is the leachate fraction.

Most data for these aquifers plot away from the conservative mixing lines in Figure 3, indicating reactive evolution in addition to simple dilution. Closer examination shows that a series of reactions occur in these leachate-impacted groundwater. In the deep aquifer, many of the DIC values show an increase in $\delta^{13} \mathrm{C}_{\mathrm{DIC}}$, which is an indication of continued methanogenesis. The excursions exhibited by a few samples to lower $\delta^{13} \mathrm{C}_{\text {DIC }}$ values are clear evidence for additions of DIC from oxidation of DOC and/or $\mathrm{CH}_{4}$.

Continued methanogenesis can account for the enrichment in ${ }^{13} \mathrm{C}_{\text {DIC }}$ observed for the groundwater that plot above the mixing line. The high concentrations of acetate measured in M32 are not present in downgradient groundwater and so have likely been lost by continued methanogenesis. The $\delta^{13} \mathrm{C}_{\text {DIC }}$ enrichment associated with this reaction is modeled in Figure 4. The average acetate concentration in M32 leachate is $1008 \mathrm{mg} / \mathrm{L}$ (Mohammadzadeh and Clark 2008). As illustrated in Figure 4, the initial input of acetate from M32 depends on the dilution factor (df) and can be calculated using Equations 3 and 4 . Fermentation of this acetate results in increased DIC and enrichment of ${ }^{13} \mathrm{C}_{\text {DIC. }}$. The final $\delta^{13} \mathrm{C}_{\text {DIC }}$ values are calculated based on a $\delta^{13} \mathrm{C}$ mass balance between initial and gained DIC components, using Equation 4,

$$
\delta^{13} \mathrm{C}_{\text {DIC-Final }}=\frac{\left(\delta^{13} \mathrm{C}_{\text {DIC-Initial }} \times \mathrm{DIC}_{\text {Initial }}\right)}{+\left(\delta^{13} \mathrm{C}_{\text {DIC-Gained }} \times \mathrm{DIC}_{\text {Gained }}\right)}
$$

in which gained DIC is obtained from percent loss of initial input acetate and its equivalent $\delta^{13} \mathrm{C}$ calculated using the following equation:

$$
\delta^{13} \mathrm{C}_{\text {DIC-Gained }}=\frac{\delta^{13} \mathrm{C}_{\text {Acetate }}+\varepsilon^{13} \mathrm{C}_{\mathrm{CO}_{2}-\mathrm{CH}_{4}}}{2}
$$

in which $\varepsilon^{13} \mathrm{C}_{\mathrm{CO}_{2}-\mathrm{CH}_{4}}$ is calculated based on ${ }^{13} \mathrm{C}$ fractionation between coexisting $\mathrm{CH}_{4}$ and $\mathrm{CO}_{2}$ (which is less than about 0.935; Whiticar et al. 1986).

The maximum $\delta^{13} \mathrm{C}$ values from this reaction do not reach the highly enriched values observed in the groundwater, which exceed $15 \%$ o to $20 \%$. Furthermore, the measured DIC concentrations are much lower than would be predicted by simple acetate fermentation. This 
Table 2

Average Geochemical and Isotopic Data for the Groundwater Samples Collected at TRL Site

\begin{tabular}{|c|c|c|c|c|c|c|c|c|c|c|c|c|}
\hline \multirow[b]{2}{*}{ Sample ID } & \multirow[b]{2}{*}{$n$} & \multicolumn{2}{|c|}{$\mathrm{H}_{2} \mathrm{O}$} & \multicolumn{2}{|c|}{ DIC } & \multicolumn{2}{|c|}{ DOC } & \multicolumn{2}{|c|}{$\mathrm{CH}_{4}$} & \multicolumn{2}{|c|}{$\mathrm{CO}_{2}$} & \multirow[b]{2}{*}{$\alpha^{13} \mathrm{C}_{\mathrm{CO}_{2}-\mathrm{CH}_{4}}$} \\
\hline & & $\delta^{18} \mathrm{O}$ & $\delta^{2} \mathbf{H}$ & $\mathrm{mg} / \mathrm{L}$ & $\delta^{13} \mathrm{C}_{\text {DIC }}$ & $\mathrm{mg} / \mathrm{L}$ & $\delta^{13} \mathrm{C}_{\text {DOC }}$ & $\mathrm{mg} / \mathrm{L}$ & $\delta^{13} \mathrm{C}_{\mathrm{CH}_{4}}$ & $\delta^{13} \mathrm{C}_{\mathrm{CO}_{2}}$ & $\delta^{18} \mathrm{O}_{\mathrm{CO}_{2}}$ & \\
\hline M57 & 2 & -13.5 & -96.6 & 53 & -15.2 & 0.9 & -28.9 & 0.00 & -50.8 & -17.9 & -0.4 & 1.035 \\
\hline M120 & 3 & -9.6 & -76.0 & 50 & -14.1 & 0.5 & -30.0 & 0.00 & -47.4 & -17.2 & 11.5 & 1.032 \\
\hline Dewatering pond & 4 & -10.9 & -76.8 & 87 & -6.7 & 1.8 & -28.9 & 0.14 & -27.2 & -12.8 & -8.6 & 1.015 \\
\hline Shallow aquifer & 12 & -12.0 & -84.3 & 187 & -6.4 & 17.5 & -28.0 & 2.67 & -56.0 & -3.3 & 8.6 & 1.051 \\
\hline Upper deep aquifer & 27 & -11.7 & -84.2 & 121 & -1.0 & 4.8 & -29.2 & 2.47 & -51.5 & -7.1 & 1.4 & 1.048 \\
\hline Lower deep aquifer & 20 & -11.8 & -84.5 & 92 & -0.6 & 3.0 & -32.3 & 2.26 & -51.4 & -7.9 & 2.9 & 1.046 \\
\hline M32 (leachate) & 3 & -70.6 & -10 & 290 & 8.5 & 4770 & -21.6 & 4.80 & -59.6 & 2.7 & & 1.066 \\
\hline
\end{tabular}

Note: All concentrations in $\mathrm{mg} / \mathrm{L}$ and isotopic values in $\%$ VPDB (for ${ }^{13} \mathrm{C}$ ) and $\%$ VSMOW (for ${ }^{18} \mathrm{O}$ and ${ }^{2} \mathrm{H}$ ), if not stated. Data for individual well are available in supporting information.

$n=$ number of values averaged.

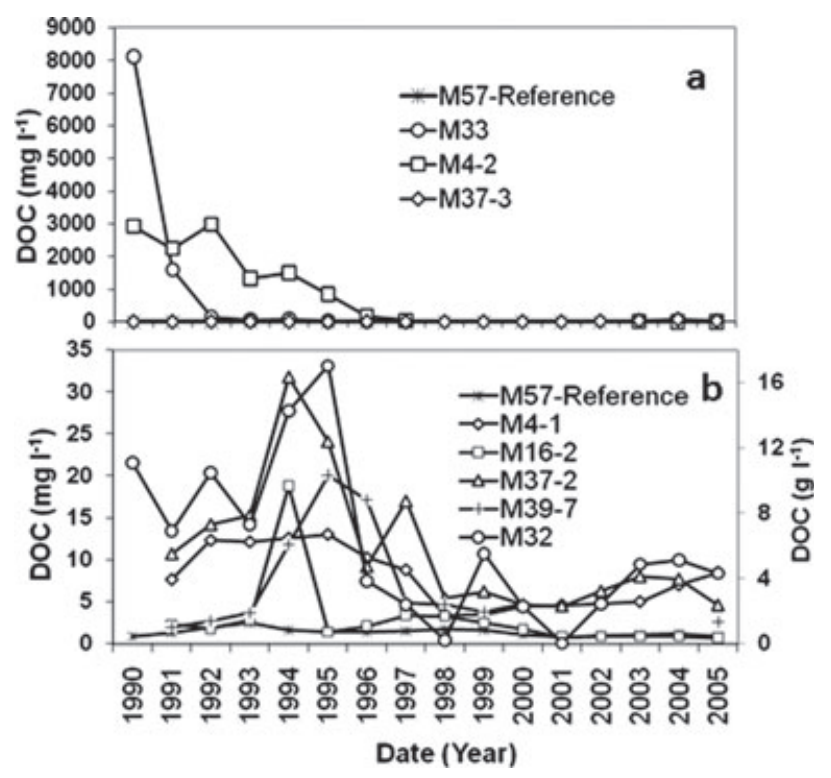

Figure 2. DOC variation (a) in shallow aquifer at M33 (top of Stage 1), M4-2, and M37-3 (north border of Stages 1 and 2, respectively) and (b) in deep aquifer at M4-1, M37-2, M39-7, M16-2 (north border of Stages 1, 2, 3, and 4, respectively), and M57 (upgradient reference groundwater) (data for the period of 1990 to 2002 from Golder Associate Ltd.). The primary axis $(\mathrm{mg} / \mathrm{L})$ applies to all data sets except M32 (leachate), to which the $\mathrm{g} / \mathrm{L}$ secondary axis applies.

suggests that DIC may have a secondary control, likely by calcite precipitation. Table 1 shows that calcite is close to equilibrium or slightly oversaturated in all groundwater and this accounts for the low $\mathrm{Ca}^{2+}$ concentrations as compared to $\mathrm{M} 32$. Any ${ }^{13} \mathrm{C}$ fractionation associated with calcite precipitation would impart a minor depletion of $\delta^{13} \mathrm{C}_{\text {DIC }}$.

In contrast, oxidation of DOC results in the depletion of $\delta^{13} \mathrm{C}_{\mathrm{DIC}}$ (Figure 4 ) and an increase in the DIC. Here, model results show that simple oxidation would produce higher DIC concentrations than measured, again suggesting a mineralogical control through calcite
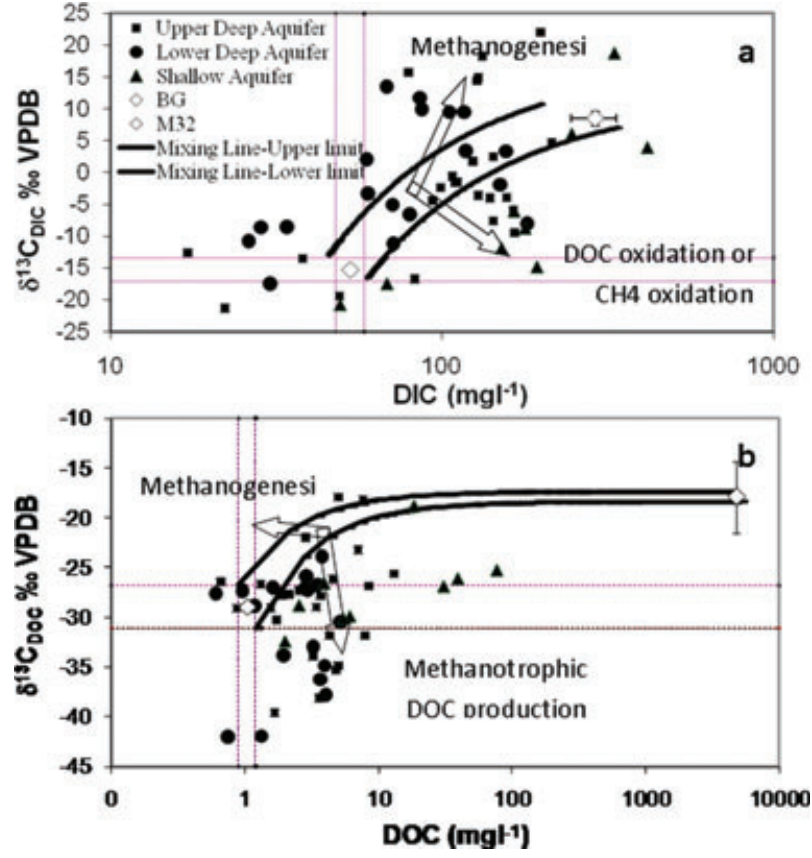

Figure 3. DIC and DOC vs. $\delta^{13} C_{\text {DIC }}$ plots for individual monitoring wells at TRL site. Included in this plot are the characteristics of leachate (from M32), contaminated groundwater, surface ponds, and BG. The dashed lines show the range of BG and the solid lines show the upper and lower limits of mixing zone between the two end members drawn based on mass balance and the range of DIC and $\delta^{13} \mathrm{C}$ in background water.

precipitation. This is further supported by the decrease in $\mathrm{Ca}^{2+}$ from over $2 \mathrm{~g} / \mathrm{L}$ in M32 to close to the background levels $(<100 \mathrm{mg} / \mathrm{L})$ in groundwater, which is greater than can be accounted for by simple dilution.

Calculated dilution of DOC in groundwater using leachate dilution factors confirms reactive loss. The leachate dilution factor $\left(\mathrm{df}_{\text {leachate }}\right)$ in the groundwater has been calculated using the $\mathrm{Cl}$ concentrations in individual samples as a conservative ion from both BG (at M57) and 


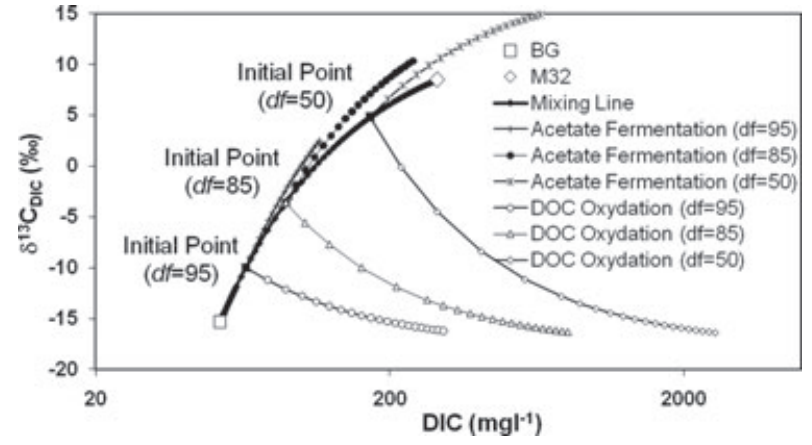

Figure 4. Modeling of the acetate fermentation and the DOC oxidation affects on total DIC and $\delta^{13} C_{\text {DIC }}$.

the leachate (at M32) end members.

$$
\begin{aligned}
\mathrm{df}_{\text {leachate }-i} & =\frac{\mathrm{Cl}_{i}-\mathrm{Cl}_{\mathrm{BG}}}{\mathrm{Cl}_{\text {Leachate }}-\mathrm{Cl}_{\mathrm{BG}}} \\
& \Rightarrow \mathrm{df}_{\mathrm{BG}-i}=1-\mathrm{df}_{\text {leachate }-i}
\end{aligned}
$$

Using the calculated leachate dilution factor, the initial concentrations and the net loss of DOC and also the net gain in DIC and $\mathrm{CH}_{4}$ have been calculated for each individual monitoring well using the following equations. The average of these values is summarized in Table 3.

$$
\begin{aligned}
\mathrm{DOC}_{\text {Unreacted }} & =\left(\mathrm{df}_{\text {leachate }} \times \mathrm{DOC}_{\text {Leachate }}\right)-\mathrm{DOC}_{\mathrm{BG}} \\
\mathrm{DIC}_{\text {Initial }} & =\left(\mathrm{df}_{\text {leachate }} \times \mathrm{DIC}_{\text {Leachate }}\right)-\mathrm{DIC}_{\mathrm{BG}} \\
\mathrm{CH}_{\text {4Initial }} & =\left(\mathrm{df}_{\text {leachate }} \times \mathrm{CH}_{4 \text { Leachate }}\right)-\mathrm{CH}_{4 \mathrm{BG}}
\end{aligned}
$$

The average amounts of net-reacted (lost) DOC for the shallow, upper deep, and lower deep aquifers are about 988,368 , and $272 \mathrm{mg} / \mathrm{L}$, respectively, which are correlated with significantly lower net gains in DIC for these aquifers (185, 117, and $85 \mathrm{mg} / \mathrm{L}$, respectively). This means that DOC is lost by production of DIC, with possible sequestration as $\mathrm{CaCO}_{3}$, and acetoclastic production of $\mathrm{CH}_{4}$

Samples from the deep aquifer exhibit highly depleted $\delta^{13} \mathrm{C}_{\mathrm{DOC}}$ ( $-32 \%$ o to $-42 \%$; Figure $\left.3 \mathrm{~b}\right)$. This is an unusual feature of DOC evolution in groundwater. Analytical artifacts arising from dissolved $\mathrm{CH}_{4}$ have been ruled out by extensive purging with $\mathrm{He}$ prior to analysis of $\delta^{13} \mathrm{C}_{\mathrm{DOC}}$ (Mohammadzadeh et al. 2005). As reported in the literature, ${ }^{13} \mathrm{C}$ values of organic material typically range from $-20 \%$ o to $-30 \%$ o (Kerfoot et al. 2003) and that of DOC originating from landfill leachate ranges typically from $-24 \%$ to $-30 \%$ o (Van Breukelen 2003). Furthermore, some leachate DOC components at the TRL are enriched to values as high as $-10 \%$ o (Mohammadzadeh and Clark 2008). Production of such highly depleted DOC in the deep aquifer is attributed to methanotrophic bacteria using ${ }^{13} \mathrm{C}$-depleted methane ( $-50 \%$ to $-60 \%$ ) for synthesis of their biomass. Subsequent degradation of this fixed organic carbon pool may then have contributed to this ${ }^{13} \mathrm{C}$-depleted DOC pool.

\section{Leachate-Impacted Groundwater: $\mathrm{CH}_{4}$ and ${ }^{13} \mathrm{C}$}

Methane is formed in the landfill by the bacterial disproportionation of light fatty acids and by $\mathrm{CO}_{2}$ reduction with $\mathrm{H}_{2}$, the two predominant metabolic pathways. The methane concentration in pristine groundwater is below the detection limit $(0.2 \mathrm{mg} / \mathrm{L})$. Near the landfill, $\mathrm{CH}_{4}$ concentrations in both the shallow and deep aquifers average about $2 \mathrm{mg} / \mathrm{L}$, although with considerable variability. Review of the data (supporting information) for the shallow aquifer indicates that M33, M4-2, and M43 (located

\begin{tabular}{|c|c|c|c|c|c|c|c|c|c|c|}
\hline \multirow[b]{2}{*}{ Aquifer } & & \multicolumn{3}{|c|}{ Measured Data } & \multicolumn{3}{|c|}{ Initial Values } & \multicolumn{3}{|c|}{ Reacted/Gained } \\
\hline & & DOC & DIC & $\mathrm{CH}_{4}$ & DOC & DIC & $\mathrm{CH}_{4}$ & $\mathrm{DOC}_{\mathrm{R}}$ & $\mathrm{DIC}_{\mathrm{G}}$ & $\mathrm{CH}_{4 \mathrm{G}}$ \\
\hline \multirow[t]{5}{*}{ Shallow aquifer } & Min & 2 & 49 & 0.0 & 34 & 19 & 0.0 & 31 & 49 & 0.0 \\
\hline & Max & 77 & 417 & 7.3 & 2332 & 89 & 2.3 & 2302 & 391 & 6.0 \\
\hline & Ave & 21 & 200 & 2.4 & 1011 & 45 & 0.9 & 988 & 185 & 3.5 \\
\hline & $\mathrm{Sdv}$ & 25 & 118 & 3 & 731 & 43 & 1 & 718 & 111 & 3 \\
\hline & $n$ & 9 & 9 & 9 & 9 & 9 & 9 & 9 & 9 & 9 \\
\hline \multirow[t]{5}{*}{ Upper deep aquifer } & Min & 1 & 17 & 0.0 & 32 & 0 & 0.0 & 28 & 17 & 0.1 \\
\hline & Max & 13 & 214 & 6.0 & 1431 & 0 & 1.4 & 1418 & 214 & 5.1 \\
\hline & Ave & 4 & 117 & 1.9 & 372 & & 0.4 & 368 & 117 & 2.4 \\
\hline & $\mathrm{Sdv}$ & 3 & 50 & 2 & 296 & & 0 & 294 & 50 & 2 \\
\hline & $n$ & 25 & 25 & 25 & 25 & 25 & 25 & 25 & 25 & 25 \\
\hline \multirow[t]{5}{*}{ Lower deep aquifer } & Min & 1 & 26 & 0.0 & 82 & 0 & 0.1 & 81 & 26 & 0.0 \\
\hline & Max & 5 & 181 & 6.2 & 515 & 0 & 0.5 & 513 & 181 & 5.7 \\
\hline & Ave & 3 & 85 & 1.8 & 274 & & 0.3 & 272 & 85 & 1.7 \\
\hline & $\mathrm{Sdv}$ & 1 & 45 & 2 & 151 & & 0 & 150 & 45 & 2 \\
\hline & $n$ & 18 & 18 & 18 & 18 & 18 & 18 & 18 & 18 & 18 \\
\hline
\end{tabular}
proximal to Stage 1) have $\mathrm{CH}_{4}$ concentrations $(3.0,10$,

Table 3

The Average Amount of Net-Reacted (Lost) DOC and Net Gained in DIC for the Shallow, Upper Deep, and Lower Deep Aquifers at TRL Site 


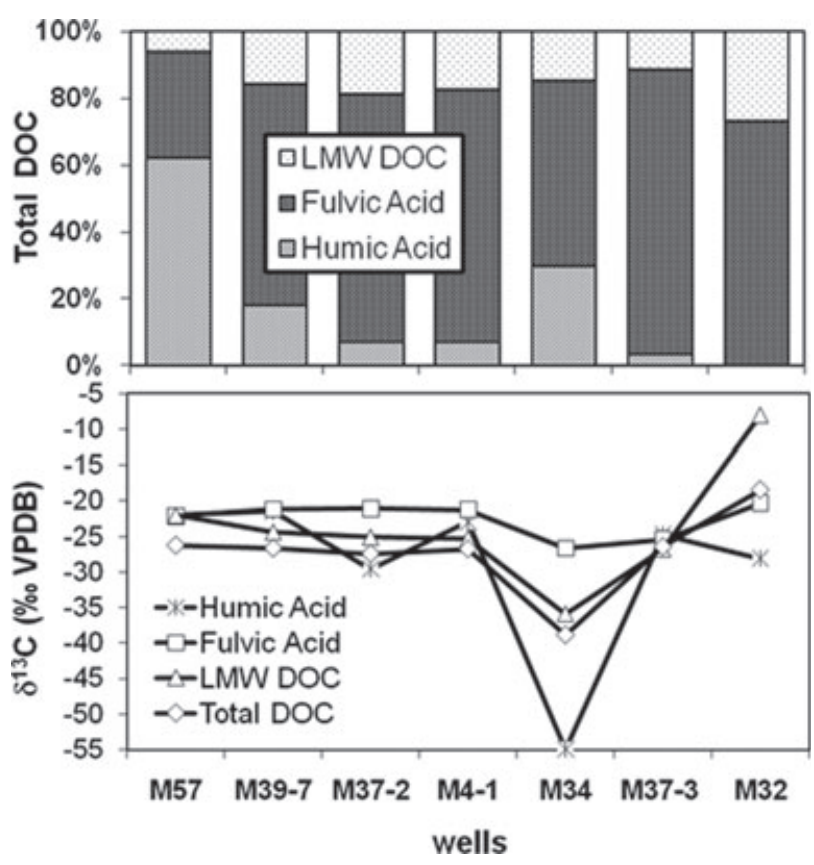

Figure 5. Distribution of humic substances as well as the variations of $\delta^{13} \mathrm{C}$ values of DOC fractions in leachatepolluted groundwater samples.

and $6.3 \mathrm{mg} / \mathrm{L}$ ) that are significantly below methane saturation. $\mathrm{CH}_{4}$ saturation is calculated to be $22 \mathrm{mg} / \mathrm{L}$ at 1 atmosphere pressure but can be greater under the higher pressures at depth below the water table. If methane in these groundwater was derived by equilibration with influxing groundwater that equilibrated with the phreatic zone atmosphere of up to $50 \%$ methane, then dissolved methane concentrations in the order of 5 to $10 \mathrm{mg} / \mathrm{L}$ could be anticipated. The upper deep aquifer beneath Stage 1 (at M32 and M28) and parallel to the north border of the landfill (at M4-1, M37-2, M23-2, M39-4\&7, M16-2, and M77-2) is also undersaturated with methane, with a maximum value of $9.9 \mathrm{mg} / \mathrm{L}$ at M4-1. The lower part of the deep aquifer (at M23-1, M39-1, and M77-1) also has minor dissolved methane. Nonetheless, these concentrations are greater than would be present in these groundwater samples by simple dilution of M32 leachate and suggests in-plume methane production.

Groundwater samples taken from shallow and deep aquifers have $\delta^{13} \mathrm{C}_{\mathrm{CH} 4}$ values (averages of $-56.0 \%$ and $-51.5 \%$, respectively; Table 2) that are $4 \%$ o to $8 \%$ o higher than the average of $-60 \%$ for primary methane from the landfill. This methane falls on the high end of the range for biogenic methane (Whiticar et al. 1986), which is consistent with production via fermentation of ${ }^{13} \mathrm{C}$-enriched acetate such as observed in M32 (-12\% ; Mohammadzadeh and Clark 2008).

\section{Leachate-Impacted Groundwater: DOC Compounds and ${ }^{13} \mathrm{C}$}

Figure 5 shows the distribution of HA, FA, and the LMW DOC fractions of leachate-impacted groundwater. In general, the high-molecular weight DOC (HA and FA) dominate the DOC of the leachate-impacted groundwater ( $76 \%$ to $87 \%$ of the total DOC content). In the BG, HA is the major fraction of the HS (62\% of the total DOC). However, in the leachate-impacted groundwater, FA is the major fraction (ranging from $55 \%$ to $85 \%$ of total DOC content) that is consistent with the leachate FA at M32 (73.2\% of total DOC content of leachate).

The LMW DOC fraction makes up $12 \%$ to $18 \%$ of the total DOC with the lowest percentages at M37-3 in the shallow aquifer and with no measureable acetate. This differs from M32, for which LMW fatty acids (acetic and propionic) dominate (average of 1008 and $608 \mathrm{mg} / \mathrm{L}$, respectively; Mohammadzadeh and Clark 2008), suggesting that this labile component of the DOC has been consumed through continued reaction in the leachate plume beyond the landfill. The calculated humic/fulvic acid (HA/FA) ratios for the leachateimpacted groundwater are below unity, which is consistent with that of M32 leachate (Table 4).

With the exception of M34 $\left(\delta^{13} \mathrm{C}_{\mathrm{DOC}}=-38.9 \%\right.$; discussed in the following section), $\delta^{13} \mathrm{C}$ of bulk DOC in leachate-impacted groundwater is close to $-26 \%$, typical of C3 type vegetation, and hence shows no indication of secondary fractionation. This is in sharp contrast with the DOC measured in M32 which shows significant enrichment in ${ }^{13} \mathrm{C}$ (average of $-21.6 \%$ ). The distribution of ${ }^{13} \mathrm{C}$ between components of the bulk DOC, tabulated in Table 4 and graphed in Figure 5, adds some insight. On average, the $\delta^{13} \mathrm{C}$ value of the LMW DOC fractions is close to the bulk value. For most sites, the $\delta^{13} \mathrm{C}$ value of FA, the major fraction of $\mathrm{HS}$, is about $-21 \%{ }^{13} \mathrm{C}$-enriched compared to that of total DOC and intermediary between that measured in M32 $(-20.3 \%$ o and background FA (M57, -22.1\%o). This suggests that the FA in these groundwater samples is simply derived from dilution of the leachate source in BG with little subsequent modification.

DOC at M34, situated on the southern boundary of Stage 1, follows a dramatically different evolution. As discussed earlier, the $\delta^{13} \mathrm{C}$ values of all DOC components and, in particular, the HA and LMW fractions are considerably depleted in ${ }^{13} \mathrm{C}$ compared to other sites. Remarkable at this site is the apparent production of HA with a much depleted $\delta^{13} \mathrm{C}$ value. This is not attributable to the DOC degradation products of organic substrates from the landfill, which show enrichments in $\delta^{13} \mathrm{C}_{\mathrm{DOC}}$ (i.e., M32 and other groundwater). Production of such ${ }^{13} \mathrm{C}$-depleted DOC can only be attributed to methanotrophic activity where the ${ }^{13} \mathrm{C}$-depleted $\mathrm{CH}_{4}$ substrate has produced fixed organic carbon with similarly depleted $\delta^{13} \mathrm{C}$ values. Degradation of this biomass could then yield the ${ }^{13} \mathrm{C}$ DOC measured in this region.

\section{Summary and Conclusions}

In leachate-impacted groundwater, concentrations and $\delta^{13} \mathrm{C}$ measured in the major carbon compounds provide a useful tool to distinguish attenuation due to biogeochemical reaction from dilution as a result of 


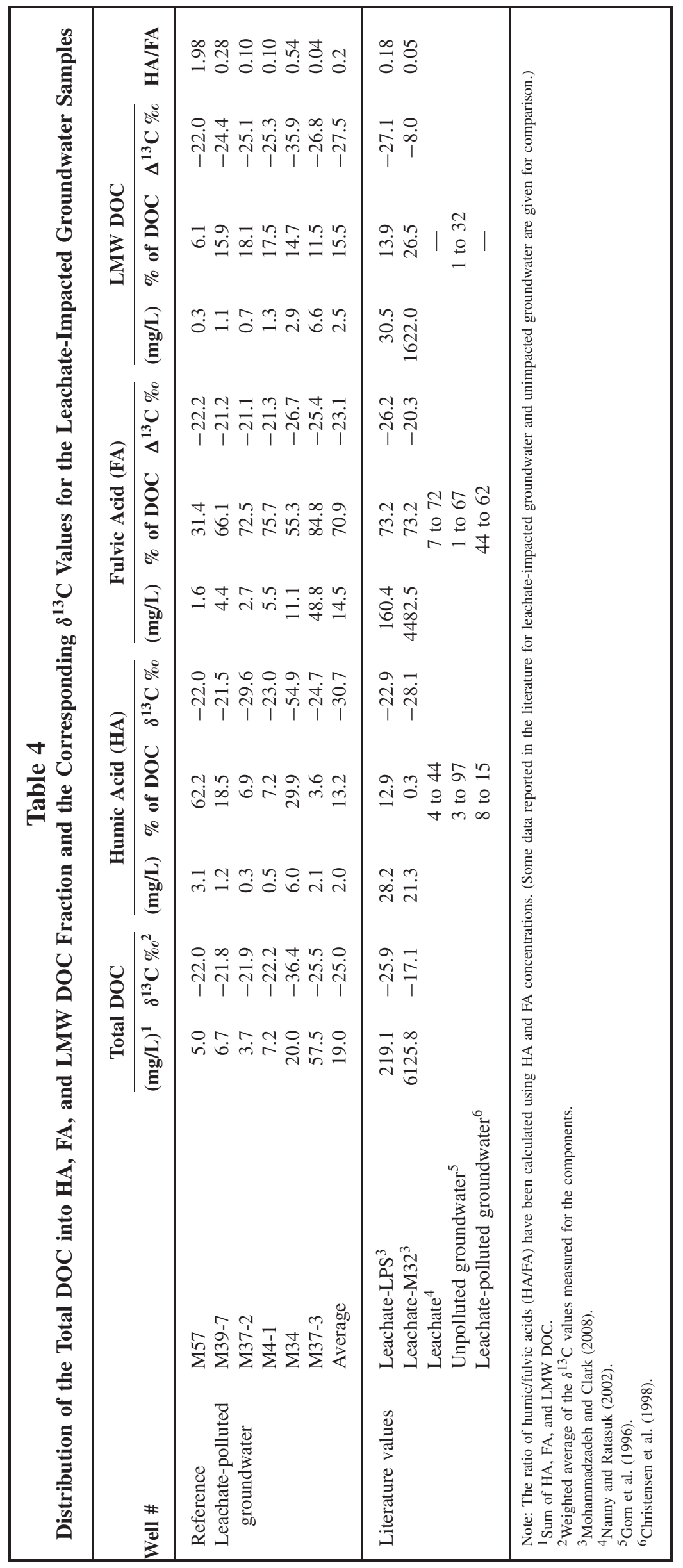


advective dispersion. The Trail Road municipal solid waste landfill site near Ontario, Canada, provides a good site to observe a range of reactions that can attenuate high DOC contributions in groundwater from leachate.

At the TRL site, both the shallow and deep aquifers have been impacted by leachate infiltrating from the unlined portions of the landfill (Stages 1 and 2). Although the $\delta^{13} \mathrm{C}$ of DOC DIC and methane demonstrate impact of landfill leachate, it is not conservative during dilution.

Consumption of DOC via acetate fermentation and oxidation of DOC within the aquifers is documented by: (1) deviation of groundwater samples from mixing lines, drawn for DIC vs. $\delta^{13} \mathrm{C}_{\mathrm{DIC}}$ and DOC vs. $\delta^{13} \mathrm{C}_{\mathrm{DOC}}$; (2) the absence of acetate in groundwater; and (3) mass balance calculations involving net-reacted (lost) DOC (988, 368, and $272 \mathrm{mg} / \mathrm{L}$ for the shallow, upper deep, and lower deep aquifers, respectively) and the net gains in DIC $(185,117$, and $85 \mathrm{mg} / \mathrm{L}$ ) for these aquifers.

Methane production by acetoclastic fermentation is reflected by the enrichment of $\delta^{13} \mathrm{C}_{\mathrm{CH} 4}$ originating in the ${ }^{13} \mathrm{C}$-enriched leachate acetate, the absence of acetate in these groundwater samples, and the associated enrichment in $\delta^{13} \mathrm{C}_{\text {DIC }}$ and calcite precipitation. Elsewhere, DIC exhibits significant depletion of ${ }^{13} \mathrm{C}$, indicating contributions from oxidation of DOC and/or $\mathrm{CH}_{4}$.

In contrast, the refractory humic and fulvic compounds show no evidence of continued reaction. In the leachate-impacted groundwater, FA is the major fraction (55\% to $85 \%$ of total DOC content), which is consistent with the leachate FA at M32 (73.2\% of total DOC content of leachate) and contrasts sharply with FA contents of unimpacted groundwater (38\% of total DOC). The ${ }^{13} \mathrm{C}$ of FA $(-21 \%)$ indicates that the FA is simply derived from dilution of the leachate source $\left({ }^{13} \mathrm{C}\right.$ of $-20.3 \%$ ) in BG $\left({ }^{13} \mathrm{C}\right.$ of $-22.1 \%$ o) with little subsequent modification.

Some groundwater from the deep aquifer have DOC that is remarkably depleted in ${ }^{13} \mathrm{C}$, with values as low as $-42 \%$. This is not possible to be generated by the degradation of organic carbon, which produces an enrichment in the residual DOC. These low values are attributed to methanotrophic bacteria that have generated a fixed organic carbon reservoir that retains the depleted $\delta^{13} \mathrm{C}$ values of the methane substrate.

In summary, the understanding of continued natural attenuation of leachate DOC in groundwater can be greatly improved through a multicomponent approach that emphasizes the analysis of ${ }^{13} \mathrm{C}$ in the different organic and inorganic carbon species in conjunction with measurements of the concentrations of other inorganic and organic compounds. In the case of the TRL, characterization of the landfill leachate and comparison with leachate-impacted groundwater show that continued attenuation of leachate-derived carbon compounds occurs via a series of reactions including acetate fermentation and DOC oxidation. Methanotrophic reactions are important in the deep aquifer, where isotopically light DOC $\left(\delta^{13} \mathrm{C}\right.$ from $-30 \%$ to $-42 \%$ o) suggests extensive biological fixation of carbon from landfill methane.

\section{Acknowledgments}

Field assistance was provided by A. Bourbonais and X. Liu. Assistance with isotope and geochemical analysis provided by G. St-Jean, P. Middlestead, W. Abdi, P. Wickham, M. Wilk, and P. Zhang in the isotope and geochemistry laboratories is gratefully acknowledged. The authors gratefully acknowledge reviews by B. Mayer, B. M. Van Breukelen, and three anonymous reviewers. Financial support was provided by NSERC (Discovery Grant to I.C.) from the School of Graduate and PostDoctoral Studies at the University of Ottawa and from the Ministry of Science, Research and Technology of Iran.

\section{Supporting Information}

Additional Supporting Information may be found in the online version of this article:

A complete data set for the concentrations and isotope values of leachate and groundwater from TRL site has been provided as "supporting information," which is available online. The results of field parameters, cations and anions, and calculated parameters (electron activity [pe], ionic strength $[I]$, and calcite saturation index $\left[\mathrm{SI}_{\text {cal }}\right]$ ), for all groundwater samples (collected from TRL site in 2003 through 2005), and the results of isotopic analysis are summarized in Tables S1 and S2, respectively. The main characteristics of the TRL leachate collected from M32 are summarized in Table S3.

Table S1. Field parameters, cation and anion concentrations, and calculated parameters (pe, ionic strength, and calcite saturation index [ $\left.\mathrm{SI}_{\mathrm{cal}}\right]$ ) for groundwater samples. All concentrations and isotopic values in $\mathrm{mg} / \mathrm{L}$ and $\% 0$ VPDB, if not stated

Table S2. Geochemical and isotopic data for the groundwater samples collected at TRL site. All concentrations in $\mathrm{mg} / \mathrm{L}$ and isotopic values in \%o VPDB (for ${ }^{13} \mathrm{C}$ ) and \%o VSMOW (for ${ }^{18} \mathrm{O}$ and ${ }^{2} \mathrm{H}$ ), if not stated

Table S3. Geochemical and isotopic data for source of contamination (leachate from M32 located in the northern part of unlined Stage 1). All isotopic data in \%o VPDB (for ${ }^{13} \mathrm{C}$ ) and \%o VSMOW (for ${ }^{18} \mathrm{O}$ and ${ }^{2} \mathrm{H}$ )

Please note: Wiley-Blackwell is not responsible for the content or functionality of any supporting information supplied by the authors. Any queries (other than missing material) should be directed to the corresponding author for the article.

\section{References}

City of Ottawa. 2002. Trail waste facility landfill operating/ expansion project, EA/EPA Document. Ottawa City, Ontario.

Christensen, J.B., D.L. Jensen, Z. Filip, C. Grøn, and T.H. Christensen. 1998. Characterization of the dissolved organic carbon in landfill leachate-polluted groundwater. Water Resources 32, no. 1: 125-135.

Desrocher, S., and B.S. Lollar. 1998. Isotope constraints of offsite migration of landfill $\mathrm{CH}_{4}$. Groundwater 36, no. 5: 801-809. 
Dillon Consulting Limited. 2006. Trail Road and Nepean landfill sites monitoring and operating reports. Report to Regional Municipality of Ottawa-Carleton. Ottawa City, Ontario.

El Fadel, M., A.N. Findikakis, and J.O. Leckie. 1997. Environmental impacts of solid waste landfilling. Journal of Environmental Management 50, no. 1: 1-25.

Fritz, S.J., F.E. Bryan, F.E. Harvey, and D.I. Leap. 1994. A Geochemical and isotopic approach to delineate landfill leachates in an RCRA study. Groundwater 32, no. 5: $743-750$.

Golder Associates Ltd. 2003. Monitoring and operating reports, Trail Road and Nepean landfills final reports. Report to Regional Municipality of Ottawa-Carleton. Ottawa City, Ontario.

Gron, C., L. Wassenaar, and M. Krog. 1996. Origin and structures of groundwater humic substances from three Danish aqiofers. Environmental International 22, no. 5: 519-534.

Hackley, K.C., C.L. Liu, and D.D. Coleman. 1996. Environmental isotope characteristics of landfill leachate and gases. Groundwater 34, no. 5: 827-836.

Hackley, K.C., C.L. Liu, and D. Trainor. 1999. Isotope identification of the source of methane in subsurface sediments of an area surrounded by waste disposal facilities. Applied Geochemistry 14, no. 1: 199-131.

Kerfoot, H.B, J.A. Baker, and D.M. Burt. 2003. The use of isotopes to identify landfill gas effects on groundwater. Journal of Environmental Monitoring 5: 896-901.

Klass, D.L. 1984. Methane from anaerobic fermentation. Science 223, no. 4640: 1021-1028.

Kjeldsen, P., M.A. Barlaz, A.P. Rooker, A. Baun, A. Ledin, and T.H. Christensen. 2002. Present and long-term composition of MSW landfill leachate: a review. Critical Reviews in Environmental Science and Technology 32, no. 4: 297-336.

Kurniawan, T.A., W.H. Lo, and G.Y.S. Chan. 2006. Physico-chemical treatments for removal of recalcitrant contaminants from landfill leachate. Journal of Hazardous Materials 129, no. 1-3: 80-100.

Liu, C.L., K.C. Hackley, and J. Baker. 1992. Application of environmental isotopes to characterize landfill gases and leachate. Geological Society of America, abstract with application, P. A35.

Lo, I.M.C. 1996. Characteristics and treatment of leachates from domestic landfills. Environmental International 22, no. 4: 433-442.

Mackay, D.M., P.V. Roberts, and J.A. Cherry. 1985. Transport of organic contaminants in groundwater. Environmental Science Technology 19, no. 5: 384-392.

Mohammadzadeh, H., and I.D. Clark. 2008. Degradation pathways of dissolved carbon in landfill leachate traced with compound-specific ${ }^{13} \mathrm{C}$ analysis of DOC. Isotopes in Environmental and Health Studies 44, no. 3: 267-294.

Mohammadzadeh, H., I.D. Clark, M. Marschner, and G. StJean. 2005. Compound specific isotopic analysis (CSIA) of landfill leachate DOC Components. Chemical Geology 218, no. 1-2: 3-13.

Nanny, M.A., and N. Ratasuk. 2002. Characterization and comparison of hydrophobic neutral and hydrophobic acid dissolved organic carbon isolated from three municipal landfill leachates. Water Research 36, no. 6: 1572-1584.

North, J.C., R.D. Frew, and R. Van Hale. 2006. Can stable isotopes be used to monitor landfill leachate impact on surface waters. Journal of Geochemical Exploration 88, no. 1-3: 49-53.

Rovers, F.A., and G.J. Farquhar. 1973. Infiltration and landfill behavior. Journal of the Environmental Engineering Division, American Society of Civil Engineers 99, no. 5: 671-690.

St-Jean, G. 2003. Automated quantitative and isotope $\left({ }^{13} \mathrm{C}\right)$ analysis of dissolved inorganic carbon and dissolved organic carbon in continuous-flow using a total organic carbon analyser. Rapid Communication in Mass Spectrometry 17, no. 5: 419-428.

Van Breukelen, B.M., W.F.M. Roling, J. Groen, J. Griffioen, and H.W. Van Verseveld. 2003. Biogeochemistry and isotope geochemistry of a landfill leachate plume. Journal of Contaminant Hyrdology 65, no. 3-4: 245-268.

Whiticar, M.J., E. Faber, and M. Schoell. 1986. Biogenic methane formation in marine and freshwater environments: $\mathrm{CO}_{2}$ reduction vs. acetate fermentation-isotope evidence. Geochemica et Cosmochemica Acta 50, no. 5: 693-709. 